2. Argyle M. K. The psychology of interpersonal behavior. Harmondsworth : University Publishing House, 1990. 336 p.

3. Dunn D. S. Psychology Applied to Modern Life: Adjustment in the 21st Century. London : Cengage Learning, 2010. 48 p.

4. Ekman P. Facial Expressions. Sussex: John Wiley and sons, 1999. 320 p.

5. Foer S.J. Extremely Loud and Incredibly Close. London : Homeworth Publishing House, 2004. 328 p.

6. Gabaldon D. A Breath of Snow and Ashes. London : Gabaldon, 2002. 659 p.

7. Hogan K. Can You Hear Your Body Talking online. URL: http://www.kevinhogan.com/body-language-detect.htm.

8. Izard C. Human Emotions. New York : Kensington Publishing House. 1977. $495 \mathrm{p}$.

9. Keyes M. Anybody Out There. New York : William Morrow Paperbacks, 2007. $464 \mathrm{p}$.

10. Miller G. A. Language and communication. New York : McGraw-Hill, 1951. $298 \mathrm{p}$.

11.Основы теории коммуникации : монография / С.И.Абрамов. Москва: Гардарики, 2003. 615 с.

12. Янова О. А. Інтенсифікація емотивного значення в номінаціях усмішки : монографія. Київ : Логос, 2000. 282 с.

УДК $811.111 ’ 373.46$

DOI: $10.24144 / 2617-3921.2020 .18 .207-216$

Ольга Алієва

кандидат філологічних наук, доцент кафедри іноземних мов для гуманітарних факультетів Львівський національний університет імені Івана Франка, м. Львів, Україна, +38(067) 2562385 , olhabox@gmail.com

\title{
Динамічний потенціал семантичного інваріанта і його вплив на процеси термінотворення
}

Анотаиія. $У$ пропонованому дослідженні розглянуто феномен семантичного інваріанта термінологічних одиниць як концептуальну систему. Значущими ї̈ рисами є складність структури і особливий характер взаємодії рівнів $і$ компонентів. Динамічний потенціал виступає однією 3 ключових характеристик функціонування інваріанта в різноманітних семантичних полях. Архітектоніці інваріанта притаманна концептуальна 
складність. Варіабельність парадигматичних відносин в межах структурних груп виявлено як необхідну передумову існування і розвитку терміноодиниць. Усі иі особливості створюють можливість градуального розвитку конотативної насиченості. Високий ступінь лабільності є характерною ознакою всіх семантичних прочесів у структурі інваріанта. Семантичний інваріант розглянуто як єдність лінгвістичних і екстралінгвальних аспектів. Складна концептуальна побудова формує потенціал розвитку полісемічного терміна. Досліджуються особливості функиіонування терміна в різних видах фахового дискурсу. Аналізуються прочеси $i$ характер змін компонентів інваріантної моделі семантичного ядра. Прочес формування окремих термінологічних кластерів, семантичних груп і полів повною мірою залежить від визначальних особливостей інваріанта. Реалізація динамічного потенціалу семантичного інваріанта є джерелом функиіонування $i$ еволюиії як усієї системи мови, так і окремих терміносистем.

Ключові слова: семантичний диференційний компонент, семантична структура, смисл, конотачія, полісемія, термінологічна система, конщепт.

Abstract. Present research deals with semantic invariant of terminological units as conceptual system. This system features complex structure and specific interconnection of levels and components. One of the key attributes of invariant functioning in different semantic fields is dynamic potential. The last one contains conceptual complexity and pragmatic relation variability within structural groups. The dynamic potential also contains connotative intensity gradual development. The development mentioned above is characterized by high liability level. Semantic invariant is considered as the linguistic and extra lingual aspects unity. The structural integrity defines the potential of polysemic term development. On the other hand, process of separate terminological clusters and various semantic groups and fields formation is defined by this structural unity. The interrelations of terminological senses have been subjected to cognitive analyses. Peculiarities of term functioning in various types of special discourse are considered. Processes and changes of invariant model components in the semantic core are analyzed. Realization of semantic invariant dynamic potential is the source of functioning and evolution of the entire language system as well as separate terminological systems.

Keywords: semantic distinctive feature, semantic structure, sense, connotation, polysemy, terminological system, concept.

Вступ. Вивчення принципів і законів семантичного розвитку як окремих термінологічних систем, так і мови в цілому є одним із важливих напрямів сучасних когнітивних теорій, теоретичної лінгвістики, загальної термінології, досліджень окремих фахових термінологій. Актуальність обраної теми зумовлена необхідністю як теоретичного, так і практичного вивчення механізмів виникнення і функціонування лексичного складу терміносистем, 
залучення синтезу наукових напрямів, як безпосередньо лінгвістичних, так i когнітивних.

Сучасні семантичні дослідження в лінгвістиці представлені різними науковими напрямами. Фреймова семантика i мовна категоризація досліджується М. Мінським, Ч.Філлмором, М. Джонсоном, Дж. Лакоффом і інш. [18; 8; 15]. Застосування підходів семантики прототипів і мовних універсалій вивчаються школами Е. Рош і А. Вежбицької [22; 26]. Напрям «філософії імені» (М.С. Трубецький, О.Ф. Лосєв, С.М. Булгаков, П.О.Флоренський), розвиває традиції семантичних досліджень, які проходять через різні історичні епохи [3; 1; 9]. Проблеми сучасного термінознавства вивчаються різними світовими термінологічними школами (С. Стааб, Р. Студер, Іващенко В. Л. і інш.) [24; 2].

Мета пропонованого дослідження - комплексне вивчення динамічного потенціалу семантичного інваріанта i його реалізації у різних випадках термінологічного i загальнолексичного вживання, i аналіз лексикосемантичних явищ у зазначеному аспекті.

Методологія та методи дослідження. Методологічна основа дослідження грунтується на комплексі методів і підходів - синтезуються методи диференційного і компонентного аналізу, аналізу лексикографічних дефініцій, підходи когнітивної лінгвістики, лексичної семантики, прототипової i категоріальної семантики. Матеріалом дослідження слугували полісемічні терміни (в тому числі терміни-словосполучення), відібрані із лексикографічних джерел, англомовної фахової літератури, електронних ресурсів.

Виклад основного матеріалу дослідження. Феномен семантичного інваріанта є складним багатоаспектним явищем, і важливе значення відіграють характер i динаміка взаємозв'язків між компонентами його структури. Розглянемо динамічний потенціал семантичного інваріанта i узагальнимо результати дослідження на прикладі полісемічного терміна-словосполучення painted lady.

Спостерігаємо процес, який ілюструє здатність до постійного семантичного розширення, що $є$ однією 3 найсуттєвіших рис інваріанта. Цілісна лексична одиниця охоплює різні семантичні поля, в тому числі і термінологічні $[27 ; 28 ; 29 ; 30]$ : мистецтво (різноманітні види жіночого зображення, в тому числі і портретного - «Painted Lady Canvas Prints; Painted Lady Framed Prints» [20]), apхітектуру (вікторіанський будинок, поверхня якого пофарбована трьома чи більш ніж трьома кольорами, що ефектно підкреслюють архітектуру - «The «Pink Painted Lady», the home is one of seven Victorians located in downtown San Francisco ...»[23]), ентомологію (мігруючий метелик переважно із помаранчово-коричневими крилами i темнішими мітками - «The UK could experience a once-in-a-decade influx of Painted Lady butterflies... »[21]), ботаніку (термін для позначення гладіолусів - "Native to Southern Africa, Gladiolus carneus (Painted Lady) is a graceful cormous perennial 
boasting loose spikes... Tough and reliable, Painted Lady Gladiolus is perfect for rock gardens ...» [10]), мінералогію, гемологію (вид напівдорогоцінного каменя - «Australian Andamooka Painted Lady opal mineral specimen lapidary collection» [4]), анімацію (ім'я персонажів відомого мультсеріалу «Аватар», яке в уявному світі серіалу носить дівчина-маг Катара, а також ім'я духа річки - «The Painted Lady actually turns out to be Katara...Seeing the Painted Lady, Aang tries to appeal to her for help, but she runs away», "After becoming a spirit, the Painted Lady began to watch over the river town...» [5]), сленг, загальновживану лексику.

Під час дослідження цікавим виявляється процес тимчасової нейтралізації певних диференційних ознак семантичного ядра, який ілюструє явища динамічності, «рухливості» (в тому числі і конотативної) в межах інваріанта при одночасному збереженні морфемної і лексичної цілісності терміна. В архітектурі, гемології, ентомології, ботаніці під час переходу словосполучення painted lady із загальновживаної лексики до складу цих терміносистем семантичний інваріант створює можливості для зміни конотативного рівня диференційних ознак від нейтрального (загальновживана лексика, частково - живопис) і негативного (сленг) до позитивного. Зокрема, як архітектурно-мистецький термін, painted lady з'явився у 1978 р., із комплексом яскраво виражених позитивних диференційних семантичних ознак, і відтінком іронії (завдяки книзі Е. Помади і М. Ларсена «Painted Ladies - San Francisco's Resplendent Victorians», де цим терміном позначались сім вікторіанських житлових будинків («Seven Sisters) у Сан-Франциско. Згодом з'явились Painted Ladies of the Charles Village in Baltimore, Painted Ladies of Old West End in Toledo, Ohio і інш.). Іронічний відтінок поступово нівелюється (наприклад, у 1885 році- «...red, yellow, chocolate, orange, everything that is loud is in fashion ... if the upper stories are not of red or blue ... they (Painted Ladies) are painted up into uncouth panels of yellow and brown ...» [7], у 2020 році «World-famous Painted Lady situated on iconic Postcard Row! This elegant 1890s Victorian has charm that radiates throughout with its high ceilings and myriad of period details. » [16]), що обумовлено і тим, що «вузол» диференційних ознак «кольорове рімення, гама», до складу якого входить система ознак - «кольори, їх естетичне, мистецьке рімення», «психологічне сприйняття» та інш. зазнає певних змін в діахронічному аспекті. Так, яскраві, барвисті тони 1849 1915 р.р. були замінені під час Першої і Другої світових війн на різні відтінки сірого (кольори залишків фарби ВМФ США), але в 1963 р. було розширено гаму кольорів.

Збереження концептуальної цілісності семантичного інваріанта i особливу роль його диференційних компонентів «висока позитивна конотація», «краса», «художність», «розкіш», що є наслідком семантичного i концептуального «злиття» інваріантів обох слів, що формують дане термінологічне словосполучення - $\epsilon$ можливим виявити і досліджуючи механізм виникнення смислів, які безпосередньо діахронічно пов'язані 3 архітектурно-історичним смислом терміна painted lady. Такими смислами є: 
назва марки джину - Painted Lady Gin - американська марка, відмічена нагородами, зі складним квітковим ароматом із лавандою, яка отримала свою назву на честь яскравих будинків (painted ladies) міста i безпосередньо етимологічно пов'язана також із таким смислом і його інваріантом - The Painted Lady Lavender Farm and Garden, що позначає дивовижну віллу 3 будинком у стилі Painted Lady i 3 лавандовим парком. Реалізацію диференційних компонентів і вплив концептуальної єдності семантичного інваріанта терміна Painted Lady простежуємо у функціонуванні вищезазначених смислів у різних видах дискурсу («Painted Lady gin ... is a deeply floral concoctio... lavender takes front and center... Consider it for breezy summers on the patio, with the salt air on your cheeks.» [14].) Функціонування i реалізація відповідних семантичних компонентів інваріанта смислу The Painted Lady Lavender Farm and Garden яскраво простежується в дискурсі і дає можливість наочно переконатися у безпосередньому впливі семантичного інваріанта цього смислу на виникнення терміна Painted Lady Gin («It isn't all about the lavender at the Painted Lady Lavender Farm and Garden. "For me, it's just the entire romance of the garden», says Sue Wallace ... Fairy-tale farm» [12]).

Доходимо висновку, що такий рівень конотації в диференційних ознаках терміна painted lady зумовлений самою природою його семантичного переходу в ці термінологічні поля, і $\epsilon$, на нашу думку, одночасно і наслідком, і однією з причин процесу метафоризації, який відбувся в даному випадку у такій формі. Вважаємо, що саме завдяки семантичному інваріанту терміна, який в даній термінологічній одиниці складається (але ні в якому разі не $\epsilon$ механічною сумою) із інваріантів двох компонентів словосполучення, а також $\epsilon$ багаторівневою семантичною структурою, стають можливими вищезгадані метафоричні переходи. В даному випадку конотація (в термінах вищезазначених терміносистем архітектури, гемології, ентомології, ботаніки, виробництва джина, у власній назві вілли з парком (йдеться про конотацію у підвищеному позитивному емоційному рівні)) лежить в основі самого виникнення досліджуваного терміна в різних термінологічних полях. Отже, це додатково ілюструє неможливість тотального застосування критерію беземоційності у термінотворенні, і неможливість дотримання відповідної вимоги до існуючих термінів, оскільки процес термінотворення є одним із природних шляхів реалізації семантичних інваріантів і розвитку мови, який неможливо штучно обмежити, тим більше, що необхідно також враховувати суттєву різницю між різними терміносистемами в синхронічному i діахронічному аспектах, у сфері денотатів і т.д. Вищезазначені процеси відбуваються, на нашу думку, завдяки складній різнорівневій структурі семантичного інваріанта, до якої входить і екстралінгвальна складова.

Динамічна організація структури інваріанта дозволяє його семантичним компонентам не тільки створювати певну ієрархію і нейтралізуватись у певних смислах функціонування терміна (i в ширшому розумінні - будь-якої лексичної одиниці), але й набувати різного ступеня інтенсивності реалізації 
(прояву) семантичної ознаки. Необхідно також підкреслити, що гама цього переходу (від прояву ознаки до її нейтралізації) $є$ абсолютно необмеженою (ніякими фіксованими позиціями). На прикладі полісемічної термінологічної одиниці painted lady реалізацію цих закономірностей можна ясно спостерігати на градації інтенсивності конотативної семантичної ознаки «позитивне сприйняття» в різних смислах у межах одного семантичного поля-категорії «людина». У смислі - терміні живопису - «види жіночого зображення, в тому числі i портретного» диференційний конотативний семантичний компонент «позитивне сприйняття, позитивна оиінка» має гнучкий спектр інтенсивності, що особливо залежить від виду і характеру дискурсу, в якому функціонує дана лексична одиниця, але потрібно відзначити, що досліджувана семантична ознака не перетинає «нульову» межу і не переходить у сталу позицію «негативність, негативне сприйняття». Наведемо приклади цього дослідженого явища: «Who is the Painted Lady? The Changing Identity of the Segar Sitter» [6] - на даному прикладі наукового дискурсу спостерігаємо нівелювання семантичних компонентів експресивної конотації у складі інваріантної структури терміна; «The Painted Lady - Tudor Portraits. Beauty at a Cost» [6] - в інваріанті проявляються нейтрально-іронічні семантичні компоненти. У такому прикладі семантичний інваріант реалізує високу інтенсивність функціонування семантичного комплексу ознак «позитивне сприйняття» - «Painted Ladies.Women at the Court of Charles II...The magnificent oil paintings of court women are some of the most sumptuous of all works of art..... a shimmering parade of Restoration Beauties.» [17]. На противагу вищеописаному такий смисл - «жінка низьких моральних якостей, легкої поведінки» виявляє стабільний ступінь інтенсивності від'ємного значення конотативного диференційного компонента «негативне сприйняття». Необхідно зауважити, що таке семантичне явище виявляється характерним для мовного домену сленгу (цей смисл $є$ також і історичним, частково архаїчним). Приклад його реалізації у дискурсі: «My sweet painted lady, the one with no name,...There's a place in the world for a woman like you.» [13].

Зберігаючи ту ж категоріальну семантичну ознаку «людина, жінка», інваріант породжує наступний смисл - «жінка, вкрита татуюванням», де досліджувана конотативна семантична ознака «позитивне сприйняття» набуває ступеня інтенсивності концепту «мистецтво», і $€$ синтезом лінгвістичних і екстралінгвальних характеристик («For every woman who simply wants a beautiful piece of artwork to decorate her body...The Painted Lady explores the styles popular ... interpretations of Vintage classics ... Eastern influences... Japanese style... tattoos by combining a number of styles to create the perfect aesthetic partnership.» [11]).

Аналізуємо під час дослідження роль інваріанта у семантичному явищі персоніфікації, і утворення іiі різних ступенів - аж до виникнення міфем. Виявляємо таку градацію семантичних рівнів персоніфікації: «камінь» (напівдорогоцінний, із тонким шаром опалу з одного боку, що створює таке 
враження, ніби кольори намальовані на поверхні [27]); «будинок» (певного архітектурного стилю); «рослина» (гладіолус); «жива істота» (метелик). В даному випадку спостерігаємо також і різні рівні метафоризації, починаючи 3 буквальної образної подібності - термін American painted lady, який позначує метелика (C. Virginiensis) з малюнком на зворотньому боці крил, що нагадує очі, - до мігруючих метеликів 3 переважно помаранчово-коричневими крилами і темнішими мітками, а також до метелика Genus Cynthia 3 чорними та білими мітками, які позначуються терміном painted lady.

Спостерігаємо також ще один рівень метафоризації, який можна вважати «подвійною персоніфікацією» - це явище переходу терміна 3 одного термінологічного поля в інше зі зміною категоріальної семантичної ознаки та зі збереженням більшості структурних і екстралінгвальних (в т.ч. візуальнообразних) характеристик i диференційних семантичних компонентів. Проілюструємо описане явище на прикладі переходу терміна 3 терміносистеми «ентомологія» у терміносистеми «ювелірна справа» і «дизайн»: в ювелірній справі - «Wallace Chan Painted Lady (Butterfly) brooch ..., created for the Biennale des Antiquaires 2012 with jadeite, diamonds, pink sapphires and rubies. The butterfly is said to be the keeper of beauty.» [25]; y дизайні (зокрема, біжутеріï) - «Painted Lady Butterfly Brooch by Vikki Lafford... Crafted in orange, ochre, black and white faux suede and cotton organdie....» [19].

Вивчаючи такий перехід рівнів метафоризації, доходимо висновку, що у складі семантичного інваріанта терміна-словосполучення може відбуватися процес зміни ступеня інтенсивності реалізації семантичних інваріантів слівкомпонентів, i їх багатоаспектної і гнучкої взаємодії в межах структури єдиного семантичного інваріанта, коли домінуюча позиція може переходити від інваріанта одного слова-компонента термінологічного словосполучення до іншого, і навпаки. До того ж, цей процес може бути настільки швидким, що відбуватиметься не тільки у межах однієї терміносистеми, а навіть у межах одного з її вузьких кластерів.

Наступним семантичним рівнем персоніфікації $є$ «людина (зокрема, жінка)», до того ж із наявністю семантично протилежних конотативних диференційних ознак в різних смислах досліджуваного словосполучення: а) у смислі - «намальована на полотні, чи будь-якому іншому матеріалі»; б) у смислі - «з низькими моральними якостями, легкої поведінки (= painted women)»; в) а також у смислі - «вкрита татуюванням» (тобто відбувається розвиток, трансформація семантичної диференційної ознаки інваріанта «матеріал, на якому здійснюється процес малювання», і під час цього процесу концептуальна структурна модель семантичного інваріанта «накладається» на іншу «основу» - полотно картини (чи будь-який інший рукотвірний матеріал) замінюється на людське (жіноче) тіло, і цей семантичний процес, як ми вже зазначали раніше, видається нескінченним, що є, на нашу думку, однією 3 найхарактерніших рис семантичного інваріанта). 
Останнім виявленим семантичним рівнем персоніфікації є «міфема» (в досліджуваному терміні - це фантастичні персонажі, наділені рисами трансцендентальності (дівчина-маг і дух річки в уявному світі серіалу)).

Висновки 3 дослідження. Дослідження динамічного потенціалу семантичного інваріанта термінологічних лексичних одиниць дає змогу поглибити уявлення про перебіг процесу утворення нових смислів полісемічного слова-терміна, а також лексико-семантичні особливості термінологічної одиниці-словосполучення. Розгляд феномена семантичного інваріанта, взаємозв'язків диференційних i категоріальних компонентів i рівнів в межах його структури і концептуальної єдності створює можливості для подальшого поглиблення розуміння природи i механізмів багатьох лінгвістичних закономірностей і явищ. Результати вивчення динамічного потенціалу семантичного інваріанта можуть бути використані для аналізу термінологічних кластерів, особливостей термінотворення у різних терміносистемах, а також зв'язків загальновживаної i термінологічної лексики. Перспективу майбутніх наукових пошуків вбачаємо в подальшому дослідженні семантичної структури феномена інваріанта та різноаспектному синтезі теоретично-прикладних підходів у вивчені зазначеної проблематики.

\section{ЛITEРАТУРА}

1. Булгаков С.Н. Философия имени. Париж: 1953. 279 с.

2. Іващенко В. Л. Фреймове $\mathrm{i}$ комунікативне термінознавство в зарубіжній лінгвістиці. Мовознавство. 2013. Вип 1. С. 51-58.

3. Лосев А. Ф. Сочинения: в 9 т. Мысль, 1993. Т.1. 959 с.

4. Australian Andamooka Painted Lady opal mineral collection . URL: https://www.ebay.com.au/itm/ T361-/112975728453 (Last accessed: 11.06.2020).

5. Avatar Wiki/Fandom.

URL: https://avatar.fandom.com/wiki/The_Painted_Lady (Last accessed: 07.06.2020).

6. Beauty at a Cost. URL: https://www.mylearning.org/stories/the-paintedlady--tudor-portraits-at-the-ferens/251 (Last accessed: 11.06.2020).

7. California Architects and Builder News. 1885. April.

8. Fillmore C.J. Frame semantics. Linguistics in the morning calm: Selected papers from the SICOL-1981. 1982. P.111 - 137.

9. Florensky P. Beyond Vision: Essays on the Perception of Art. London.2002.320 p.

10. Gladiolus carneus (Painted Lady). Gardenia. Creating Gargens. URL: https://www.gardenia.net/plant/gladiolus-carneus (Last accessed: 05.06.2020).

11. Holmes D. The Painted Lady: The art of tattooing the female body. London: Ryland Peters \& Small, 2013. 128 p. 
12. Hume R. Word Nerd: Painted Lady. Coast Weekend. 2018. September 5.

13. John E., Taupin B. Sweet painted lady. Album: Goodbye Yellow Brick Road. URL: https://www.songfacts.com/facts/elton-john/ (Last accessed: 05.06.2020).

14. Korfhage M. Drank: Painted Lady Gin. URL: https://www.wweek.com/portland/article-22726. (Last accessed: 11.06.2020).

15. Lakoff G., Johnsen M. Metaphors we live by. London. 2003. 256 p.

16. Larson E. Painted Lady house on San Francisco's «Postcard Row» up for sale. URL: https://www.kron4.com/news/bay-area/ (Last accessed: 12.06.2020).

17. MacLeod C., Alexander J.M. Painted Ladies.Women at the Court of Charles II. London: National Portrait Gallery Company Limited. 2020. 256 p.

18. Minsky M. A Framework for Representing Knowledge. Psychology of Computer Vision. New York, 1975. P. $211-277$.

19. Painted Lady Butterfly Brooch by Vikki Lafford. URL: https://www.cambridgecrafts.co.uk/vicki-lafford/ (Last accessed: 12.06.2020).

20. Painted Lady. https://pixels.com/art/painted+lady (Last accessed: 05.06.2020).

21. Roberts L. «Millions» of Painted Lady butterflies set to arrive in the UK this summer. The Telegraph. 2019. July 19. URL: https://www.telegraph.co.uk/news/2019/07/18/ (Last accessed: 07.06.2020).

22. Rosch E.H. Human Categorization. Advances in Cross-Cultural Psychology. 1977. Vol. 1. P. 1-72.

23. Scipioni J. This is what a $\$ 2.7$ million «fixer-upper» looks like in San Francisco. URL:https://www.cnbc.com/2020/01/14/ (Last accessed: 11.06.2020).

24. Staab S., Studer R. Handbook on ontologies. Berlin: Springer-Verlag,2004. $660 \mathrm{p}$.

25. Wallace Chan at the Biennale 2012. The Jewellery Editor. URL: http://www.thejewelleryeditor.com/jewellery/article/wallace-chan-at-thebiennale-2012/ (Last accessed: 05.06.2020).

26. Wierzbicka A. Two levels of verbal communication, universal and culturespecifi. Verbal Communication. 2016. P. 447-481

\section{СПИСОК ЛЕКСИКОГРАФІЧНИХ ДЖЕРЕЛ}

27. Australian

English

Dictionary.

URL: https://australian_english.enacademic.com/75927/

(Last accessed: 05.06.2020). 
28. Collins English Dictionary. New York, 2006. URL: https://www.abbyy.com/en-ee/translation_dictionary (Last accessed: 10.06.2020).

29. Macmillan

Dictionary.

London,

2010.

URL: http://www.macmillandictionary.com. (Last accessed: 11.06.2020).

30. Oxford Dictionary of English. Oxford, 2010. URL: https://www.abbyy.com/en-ee/translation_dictionary (Last accessed: 11.06.2020).

УДК 811.111-112:81’371

DOI: $10.24144 / 2617-3921.2020 .18 .216-225$

Сніжана Голик

кандидат філологічних наук, дочент, завідувачка кафедри англійської філології ДВНЗ “УжНУ”

ORCID 0000000312783383

Ужсгород, Україна, +380503727340,

snizhana.holyk@uzhnu.edu.ua

\section{Етимологічний шар концепту OLD AGE}

Анотаиія. Останні десятиліття характеризуються посиленням уваги науковиів до проблем старіння та людей похилого віку. Метою аналізу у запропонованій статті є комплексне дослідження концептуалізаџї̈ старості в англомовній картині світу. $У$ статті представлено результати встановлення передконщептуальних засад OLD AGE шляхом визначення етимону та внутрішньої форми лексеми old age - імені концепту та ї̈ синонімів. Актуальність дослідження визначається зверненням до історичного розвитку вербалізованих концептів, щуо сприяе аналізу мови 3 точки зору ї̈ участі у когнітивній діяльності людини. Визначення етимологіі ключової лексеми дозволяє зрозуміти послідовність становлення семантичних ознак кониепту. Об'єктом розвідки є концепт OLD AGE, вербалізований лексичними одинииями англійської мови. Предмет дослідження-особливості етимологічного розвитку номінативної лексеми old age, ï̈ синонімів та прикметника old, a також встановлення асоціацій, релевантних поняттю “старість". Матеріалом слугували як теоретичні розробки сучасних лінгвістів, присвячені дослідженню етимології концептів та їхньому історичному розвитку, так і етимологічні словники англійської мови. Зроблено висновок про те, що встановлення етимології імені концепту передбачає проведення етимологічного лексикографічного аналізу засобів його мовного вираження. Поняття внутрішньої форми відображає образи та 